\title{
Reading Comprehension in an English as a Foreign Language Setting: Teaching Strategies for Sixth Graders Based on the Interactive Model of Reading
}

\author{
Comprensión de lectura en inglés como lengua extranjera. \\ La enseñanza de estrategias para estudiantes de sexto grado a partir \\ del modelo interactivo de lectura \\ Compreensão de leitura em inglês como língua estrangeira. \\ O ensino de estratégias para estudantes de sexto ano segundo \\ o Modelo Interativo de Leitura.
}

Ángela María Gamboa González ${ }^{1}$

\section{Abstract}

This article presents the results of an action research which attempted to describe and analyze sixth graders' reading comprehension processes in an English as a foreign language setting through the implementation of strategies based on the Interactive Model of reading in the reading plan project at a private school in Bogotá. Twenty students from sixth grade participated in the study for over six months during 2012. Data were collected through students' journals, artifacts, two questionnaires and field notes. The findings revealed that the activities based on the Interactive Model of reading helped students comprehend the stories they read, giving them the opportunity to interact with the text, the writer and their partners in order to create meaning. Moreover, students were able to activate their schemata using their previous knowledge and experiences, make predictions, confirm their guesses, compensate weaknesses using interactive processes proposed in the Model and construct meaning collectively. This project was also an example of how a psycholinguistic model could be converted into instructional practice inside a classroom.

\section{Keywords}

Reading comprehension, English as a foreign language, Interactive Model of reading, schema theory, action research

\section{Resumen}

Este artículo presenta los resultados de una investigación acción que buscaba describir y analizar los procesos de comprensión de lectura en inglés como lengua extranjera en estudiantes de grado sexto con la implementación de estrategias basadas en el modelo interactivo de lectura en el plan lector de un colegio privado de Bogotá. Veinte estudiantes de grado sexto participaron en el estudio por casi seis meses durante el año 2012. Los datos fueron recolectados a través de los diarios de los estudiantes, artefactos, dos cuestionarios y notas de campo. Los resultados revelaron que las actividades basadas en el modelo interactivo de lectura ayudaron a los estudiantes a comprender las historias leídas, dándoles la oportunidad de interactuar con el texto, el escritor y sus compañeros con el fin de crear significado. Además, los estudiantes pudieron activar esquemas usando su conocimiento previo y experiencias, hacer predicciones, confirmar sus suposiciones, compensar debilidades haciendo uso de procesos interactivos propuestos en el modelo y construir significado colectivamente. Este proyecto fue también un ejemplo de cómo un modelo psicolingüístico pudo ser transformado en práctica de enseñanza en el salón de clase.

Palabras clave

Comprensión de lectura, inglés como lengua extranjera, modelo interactivo de lectura, Teoría de esquemas, investigación acción

1 Universidad Uniminuto, Bogotá, Colombia. Correo electrónico: angelam_83@yahoo.es - angela.gamboa@uniminuto.edu 


\section{Resumo}

Este artigo apresenta os resultados de uma investigação ação que procura descrever e analisar os processos de compreensão de leitura em inglês como língua estrangeira em estudantes de sexto ano com a implementação de estratégias baseadas no Modelo Interativo de leitura no plano de leitura de um colégio privado em Bogotá. 20 estudantes de sexto ano participaram no estúdio por quase seis meses no ano 2012. Os dados foram coletados através dos jornais dos estudantes, artefatos, dois questionários e notas de campo. Os resultados revelaram que as atividades baseadas no Modelo Interativo de leitura permitiram que os estudantes pudessem compreender as histórias lidas, com a oportunidade de interatuar com 0 texto, 0 autor e seus companheiros, criando, assim, significado. Além disso, os estudantes puderam ativar esquemas utilizando seu conhecimento prévio e experiências, fazer predições, confirmar suas suposições, compensar fraquezas utilizando processos interativos abordados no Modelo e construir significado coletivamente. Esse projeto foi também um exemplo de como um modelo psicolinguístico pode se transformar em prática de ensino na sala de aula.

\section{Palavras chave}

Compreensão de leitura, inglês como língua estrangeira, Modelo interativo de leitura, Teoria de esquemas, Investigação ação

\section{Artículo recibido el 30 de octubre de 2015 y aprobado el 5 de agosto de 2016}

\section{Introduction}

Reading effectively in a foreign language is one of the most challenging activities for many students at school. Certainly, this important skill helps students succeed in their learning process at school and in their lives in general (Dechant, 1991). In my experience as an English teacher at a private school in Bogotá, I could notice that sixth grade students had problems when facing books in the foreign language due to the fact that they did not have the linguistic tools to read in an effective way and they did not know how to understand the texts without translating all the words using a dictionary. In other words, most of the students from that grade needed to improve their reading comprehension skills in English during the activities of the reading plan established at the school. Taking into account the aforementioned issues, this research project emerged with the intention of promoting and developing reading comprehension strategies in English as a foreign language for sixth graders to provide them with enough elements to create meaning when they interacted with the texts.

For years, several authors have studied the ways in which reading could be taught effectively. At the beginning, the conception of reading was merely that of a decoding process (Carrell, 1998). In contrast, authors such as Dechant (1991) affirm that reading is about meaning and comprehension of meaning. As she says "comprehension is the goal and purpose of reading. Without it there is no reading" (p. 9). Indeed, reading involves not only the recognition of printed symbols but the development of meaning to the words the writer intends to transmit. Comprehension of the text is the essence in the reading process.

Many researchers argue that reading in a foreign language is similar to reading in the first language. Goodman (1982) points out that the reading process is universal for all the languages since making meaning from written texts happens in all of them. According to Zúñiga (2001), reading in a first language and a foreign language are processes that share many things. This author states, with Goodman (1982), that both are meaning making processes from printed texts. Moreover, both are transactions between the reader, the text and the context. Both depend on prior knowledge, knowledge of cue systems, and use of cognitive and affective strategies; and both are vehicles for getting or changing knowledge (p. 105).

Although reading in the first language shares important elements with reading in a foreign language, these processes also have significant differences. Zuñiga (2001) also claims that reading in a foreign language implies certain linguistic aspects such as the difference between writing systems and 
sounds or the lack of knowledge and competence in the foreign language. In fact, problems in handling the code (vocabulary and grammar) can be obstacles in the comprehension process. Moreover, the construction of meaning is hampered due to the absence of a cultural context from which the reader can build the message.

The above mentioned aspects show how complex the reading process is. Therefore, implementing effective reading comprehension strategies inside the classroom was a great challenge as there are many of them that might help students use efficient ways to read comprehensively in the foreign language. For example, Navarro (2008) proposed different strategies to help her students build background knowledge and activate their schemata to interact with the texts and create meaning. Another study developed by Rodríguez and Rodríguez (2009) describes the methodology applied to identify the reading strategies used by bilingual students in high school. In addition, in this study, it is mentioned that there exist two crucial reading models that allow students to construct meaning from the texts. They are the bottom-up models and the top-down models.

Taking into account the previous studies, a deep search was done regarding different psycholinguistic models in order to understand how texts are processed and which strategies based on them could be transferred to an instructional field in an English as a foreign language setting. One of the reading models that includes some of the aspects mentioned before and some others which were relevant to be developed in depth is the Interactive Model of reading. This model suggests that the reader is the one who makes the decision of giving meaning to the words and sentences he/she reads using different strategies in order to comprehend and understand what the writer wants to transmit (Carrell, 1998). With strategies based on the Interactive Model of reading the readers might have the possibility to interact with the text using the tools and elements provided in order to make the process less complex and allow them to achieve the principal goals when reading, comprehending and creating meaning.

\section{Theoretical Framework}

\section{The reading comprehension process}

Many years ago reading in English as a foreign language was perceived as a passive process. It was conceived as a decoding process of reconstructing the author's intended meaning by means of recognizing the printed letters and words, and building up a meaning for a text from the smallest textual units at the bottom which are letters and words to larger units at the top like phrases, sentences, clauses (Carrell, 1998).

Problems of second language reading and reading comprehension were viewed as being essentially decoding problems. Moreover, Carrell (1998) explains that before 1970 the process of reading in a foreign language was viewed as an attachment to oral language skills. The audio-lingual method implemented in the 1970s played down the importance of reading skills and dictated the primacy of listening over the others; also the importance given to the grapheme and phonemes by the structuralists was responsible for the implementation of the decoding perspective in second language reading.

On the other hand, some other authors have a very different point of view about the reading process in a foreign language. According to Grabe (1998), in the 1980s the accepted theories about reading as decoding process changed dramatically. Thanks to authors such as Rumelhart (1980), Johnson (1981), Carrell and Eisterhold (1998) among others, the reading process was not simply a matter of extracting information from the texts but a process in "which the reading activates a range of knowledge in the reader's mind that he or she uses, and that in turn, may be refined and extended by the new information supplied by the text" (Grabe, 1998, p. 56).

Another view of the reading process is the one mentioned by Dechant (1991). She points out that reading is a process to succeed in school; it is the key to the development of out-of-school interests, to the enjoyment of leisure time and to personal and social adjustment. This author makes special emphasis on the idea that reading helps children become independent of parents and teachers, select and prepare 
for an occupation, and achieve social responsibilities. But among all these aspects, Dechant claims that effective reading is the most important way to effective learning, "reading is so interrelated with the total educational process that educational success requires successful reading" (p. 7).

Goodman (1998) defines reading as a receptive language process. He states that it is a psycholinguistic process which starts with a linguistic surface representation encoded by a writer and ends with meaning constructed by the reader. Based on this author's statement, it can be said that in this process there is an essential interaction between language and thought. He argues that "the writer encodes thought as language and the reader decodes language to thought" (Goodman, 1998, p. 12).

During the reading process it is the reader who has the role of giving meaning to the words and sentences he reads in order to build knowledge. The construction of meaning involves the reader connecting information from the written text with previous knowledge to arrive at meaning or understanding.

Having seen these different perspectives of reading, it is necessary to go deeper in the principal models proposed attempting to describe how people process texts, and lay an especial emphasis on the one selected for this research project as well. The models are often categorized as bottom-up, topdown and interactive models of reading.

\section{Bottom-Up Model}

In bottom-up theories, meaning resides in the text. This point of view shows this process as an essentially passive process, where the reader decodes the intended message of the writer by moving from the lowest level, such as letters and words, towards the higher levels of clauses, sentences, and paragraphs (Carrell, 1998). This implies that the meaning comes from deciphering the letter, then the word, the sentence and finally the text. In other words, the process is conceived of as something unilateral in which the reader only has the role of extracting written information and constructs meaning from the particular text segment that is being processed without taking into account the surrounding environment.
One bottom-up model, described by Urquhart and Weir (1998) taking into account Gough's model mentions that a number of processing components are used in order to process text. His description shows the reading process from the perception of the letters which make up the text, through an oral realization of it. The reader begins with letters, which are detected by the scanner, and then the strings of letters are converted into phonemes by the decoder. The output of the decoder then arrives to the recognition of a word. The reader then continues by fixating on the next word in the text until every word in the sentence has been analyzed.

The bottom-up or decoding model of reading was criticized by Eskey (1998) for its failure to account for the contribution of the reader and his expectations about the text, which are informed by his knowledge of language, and are employed as part of the reading process. The perceived importance of the reader's expectations in the processing of text led to the development of the top-down model of reading.

\section{Top-Down Model}

Goodman (1982) is closely related to top-down approaches of reading. He argues that readers bring a great deal of knowledge, expectations, assumptions and questions to the text and, given a basic understanding of the vocabulary, they continue reading as long as the text confirms their expectations. The top-down school of reading theory claims that readers fit the text into (cultural, syntactic, linguistic, and historical) knowledge they already possess and then check back when new or unexpected information appears.

As a complement, some other authors mention that the top-down model comprehends reading not as the bottom-up processing of words, and that the meaning is not entirely residing in the text. The knowledge, experience and concepts that the reader brings to the text, in other words, his/her schemata, are a very important part in the process (Dechant, 1991, p. 25).

In Urquhart and Weir's words (1998), the reader brings expectations to the text and continues making predictions as he/she samples the text, while he/ she omits parts of the text which he considers to be unimportant. If the predictions made seem to be incorrect, the reader will return to read the text 
more carefully in order to create further predictions. Urquhart and Weir point out, "Goodman views reading as a process of hypothesis verification, whereby the readers use selected data from the text to confirm their guesses" (1998, p. 42).

Besides, Goodman (1998) offers a revised model of the reading process. He perceives reading as a cycle, in which the reader samples the text continuously in order to construct meaning. In his model there are five processes used during the reading. These are recognition-initiation, prediction, confirmation, correction and termination.

The first process, recognition-initiation process is where the "brain must recognize a graphic display in the visual field as language and initiate reading" (Goodman, 1998, p. 16). The prediction, confirmation and correction processes are strongly connected.

The brain makes predictions which are either confirmed or found to be incorrect at the confirmation level, depending on the input received. If a prediction is determined to be incorrect, the brain will reprocess and formulate a new prediction based on the previous input. The termination process is where reading stops, at the end of the reading task.

Nevertheless, the bottom-up theorists disagree with the last point of view, especially with Goodman's perception. Rayner and Pollatsek (1989) argue that visual processing of a text occurs very fast and that the extent to which readers engage in hypothesis testing or guessing behaviors seems to play a minimal part in the process of reading.

The most relevant characteristic of the top-down theory is that reading is perceived as a subset of problem solving rather than as a simply automatic matching of linguistic responses to linguistic stimulus. The belief that both top-down and bottom-up processing are important characteristics of the behavior of a skilled reader led to the development of interactive theories of reading.

\section{Interactive Model of Reading}

The interactive model assumes that all bottom-up and top-down processes interact. In fact, the term interactive can be interpreted in two ways as said by Hedge (2000). The first one describes the relationship created between the reader and the text while the reader tries to make sense of it. In this process of meaning building the reader is totally involved in an active process where he combines information from the text and his/her previous knowledge and experiences. In Hedge's (2000) words "reading can be seen as a kind of dialogue between the reader and the text, or even between the reader and the author" (p. 188).

The second interpretation of the term interactive refers to the interplay among the different types of knowledge a reader uses to make sense of a text. There are at least six types of knowledge mentioned by Hedge (2000): syntactic knowledge, morphological knowledge, general world knowledge, sociocultural knowledge, topic knowledge, and genre knowledge. Two of these, syntactic and morphological, are to do with the language itself and help the reader decode the language of a text; they are both linguistic and are called systemic knowledge. In the same way, the other kinds of knowledge help the reader work with the language of the text in order to give meaning to it. They are called schematic knowledge.

In particular, the model proposed by Rumelhart (1980) explains the previous concepts. It is called interactive-activation model. Rumelhart's theory suggests that each level of information, from grapheme to word, is separately represented in the memory and that information passes from one level to the next in both directions, which is what he calls interaction. The diagram in Figure 1 shows his proposal. 
Universidad Pedagógica Nacional

Facultad de Humanidades

Figure 1. Rumelhart's Interactive Model. (Cited in Dechant, 1991, p. 29)
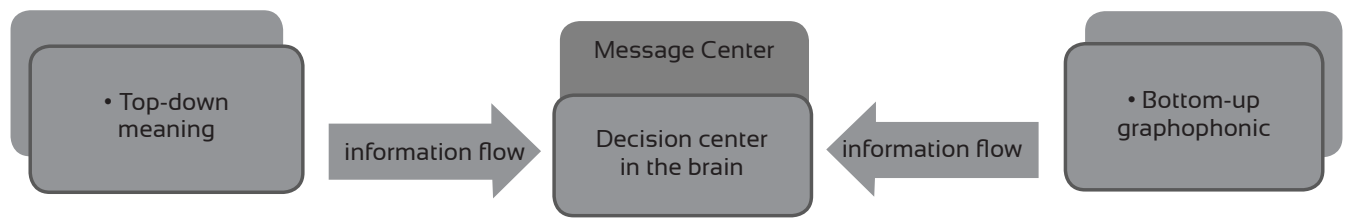

This model is explained in depth by Samuels and Kamil (1998). According to the diagram, the knowledge sources such as semantic, syntactic, lexical, orthographic, general world, genre, etc. (systemic and schematic knowledge) provide input simultaneously and the message center holds the information and redirects it as needed. The message center has different functions: as each of the knowledge sources feeds in information about the text being processed, the center holds the information in a temporary store. Each of the sources may use the information provided by one or more of the other sources. The message center permits the knowledge sources to communicate and interact with others in order to create meaning while reading.

Turning to the interactive model pertinent for this research study, it was the one proposed by Stanovich (1980). He refers to his model as interactive compensatory. The interactive-compensatory model of reading was developed primarily to explain developmental and individual differences in the use of context to facilitate word recognition during reading. Samuels and Kamil (1998) explain this model as an interactive model of reading that allows compensating weaknesses in any of the processing levels by processes at other levels.

For example, if a reader has a weakness at the level of word recognition, he/she can compensate this by the use of knowledge about the topic of the text. Therefore, top-down processing could compensate weaknesses in bottom-up processes. In contrast, a reader who has little knowledge about the topic of a text can compensate this deficiency if he/she is skilled at word recognition by relying more on bottom-up processes. The Stanovich model is interactive in the sense that any stage, regardless of its position in the system, may communicate with any other stage, and it is compensatory in the sense that any reader may rely on better developed knowledge sources when particular, and usually more commonly used, knowledge sources are temporarily weak (Samuels \& Kamil, 1998). This interactive-compensatory model implies the interaction between the two processes to achieve comprehension, aspects which were worth taking into account when proposing the activities for sixth grade students.

It is known that interactive theories of reading have been embraced by many writers interested in the teaching of second language reading. Nuttall (2000) writes that top-down and bottom-up processing are "complementary ways of processing a text. They are both used whenever we read, sometimes one predominates, and sometimes the other, but both are needed" (p. 16). She also adds that "in practice a reader continually shifts from one focus to another, now adopting a top-down approach to predict the probable meaning, then moving to a bottom-up approach to check whether that is really what the writer says" (p. 17). In any case the interaction is presented.

Another view of reading based on the interaction presented between the reader and the text includes according to Birch (2007) three principal aspects: The different processing strategies, both top and bottom, along with the knowledge base, interact with each other in order to accomplish the reading. The second aspect mentions that the reader's mind interacts with the written text so that the reader can understand the message. And finally, the reader interacts indirectly with the writer of the text, trying to give meaning to the message the writer wants to communicate. 
Reading Comprehension in an English as a Foreign Language Setting: Teaching Strategies for Sixth Graders Based on the Interactive Model of Reading

Ángela María Gamboa González /

Works by the different authors mentioned before led to reading being regarded as an interactive rather than a passive process. According to this view, the reading process involves the activation of knowledge in the mind of the reader. This knowledge is then used by the reader and may be extended or refined according to the new information provided by the text (Grabe, 1998). In this sense, meaning is not seen as something provided by the text, as it was proposed in the bottom-up theory, but it is created as a result of the interaction between the reader and the reading.

This conception of reading as interaction is related to the interactive-compensatory model. As was noted earlier, the model presented by Stanovich (1980) and explained by Samuels and Kamil (1998) allowed for the reader's background knowledge to compensate for deficiencies in bottom-up processes. It is very important to highlight that in the classroom it is necessary to pay attention to both processes and help students activate the needed knowledge to create meaning.

The role of background knowledge in reading comprehension has been formalized as schema theory. The schema theory is focused on the way the schematic knowledge may be activated to help the learner in the reading process. According to this theory, the comprehension of a text is an interactive process between the readers' background knowledge and the text. It is concerned with the abstract knowledge structures the reader possesses based on her/ his prior experiences, and which may be activated in the mind of the reader and utilized as she or he tries to interpret the text (Carrell \& Eisterhold, 1998).

Schema theory confirms that background knowledge is important within a psycholinguistic model of reading. This theory comes under the influence of Goodman (1982) in his psycholinguistic theory. Inside the classroom teachers need to recognize the importance of building background knowledge and helping students activate the schemata by implementing different strategies such as pre-reading, communicative pre-reading, vocabulary instruction, visual cues, questioning methods, comprehension instruction, and appreciating their culture, as Navarro (2008) proposed in her study.

\section{Methodology}

The project was a qualitative action research. Qualitative because, taking into account the definition proposed by Gerson and Horowitz (2002), "it involves some kind of direct encounter with the world, whether it takes the form of ongoing daily life or interactions with a selected group" (p. 199). These authors also affirm that in qualitative research the researchers are not only concerned with measurable facts or events as in quantitative research, but also with the ways that people construct, interpret and give meaning to these experiences. Besides, this paradigm of research offers the possibility to describe and interpret in a detailed way the findings provided by the data in order to understand the phenomena.

Taking into account that it was developed based on a specific problem identified in a specific context, this research followed an action research approach. In this approach, the participants have an active role and work with the researcher proposing alternatives to solve the situation that affects them. Moreover, action research allows the reflection to bring about change and improvement in practice (Burns, 2003).

In order to complement the last statement, it is necessary to emphasize on the idea implicit in the term action research, which is that teachers as researchers will begin a cycle of posing questions, gathering data, reflection, and deciding on a course of action. When these decisions begin to change the school environment, a different set of circumstances appears with different problems posed, which require a new look (Ferrance, 2000).

Furthermore, this research study focused on a process that was explored and observed; the purpose was to solve a problem by leading different actions in a particular context. According to Johnson and Christensen (2004), "Action Research is focused on solving specific problems that local practitioners face in their schools and communities" (p. 11). Also, it provides the elements and information necessary to explain phenomena and improve the educational practices. 
With action research I had the opportunity to recognize the strengths and the aspects to improve in my daily practice reflecting about my own teaching process, so I was able to make the changes that benefited my students. As Ferrance (2000) points out, "Research and reflection allow teachers to grow and gain confidence in their work. Action research projects influence thinking skills, sense of efficacy, willingness to share and communicate, and attitudes toward the process of change" (p. 14). In other words, through action research teachers learn about themselves, their students, their colleagues, and can determine ways to continually improve.

\section{Setting}

This study took place at a private school. It is located in Engativá, one of the urban sectors of Bogotá, Colombia. This is a private mixed school, which means boys and girls studying together. It has a population of 3700 students. The school has established six English hours per week, including two hours in the lab for elementary school and one lab hour per week for high school. There are two or three English teachers per grade, and there are six or seven groups of 40 or 41 students in every grade.

The English classes are developed following a "trimester planning" that is designed at the beginning of the term and is based on the concepts from the text book; it also includes one hour for the reading plan. For this plan, the students have to read one book each term; the library of the school has a wide selection of books that are organized according to the students' ages and levels. Each teacher has to choose the possible titles to read in the grade and plan the activities to develop the program.

\section{Participants and sampling}

Participants: the students I worked with during the implementation of strategies based on the Interactive Model of reading were from sixth grade. They were between 11 and 12 years old. These children enjoy sharing their opinions and feelings and try to use the elements given in class so that the others understand them, whether in English or in their mother tongue. These students come from middle class homes so they have the possibility to access to different resources that complement their learning process. Also, most of the students in this grade have studied in the school for more than three years so they have been working with the reading plan since elementary school. This information was gathered from the first questionnaire applied to the students at the beginning of the intervention.

\section{Sampling}

The sampling for this research can be classified into the purposive or purposeful sampling, as Merriam (1998) called it, because it is based on the assumption that the researcher has the willingness to discover, understand and gain insight by selecting a sampling from which the most can be learnt. The type is a typical sample because the participants selected have similar characteristics that reflect the average situation of sixth grade students at school.

I implemented the strategies based on the model in the groups I worked with, but I collected the data from 20 students, 10 boys and 10 girls in 6G because I was the homeroom teacher of this group and I knew the students better so I had more opportunities to interact with them.

\section{Data Collection Instruments and Procedures}

After some weeks of piloting several instruments and recognizing their advantages and disadvantages, four of them were used to obtain the information required to support the study. First, field notes were written after each reading plan session (16 sessions). This instrument allowed me to describe in a detailed way the things that called my attention along the implementation of the strategies and as they were taken in a rigorous way, they provided me with reliable and valid information that supported the research. Second, two questionnaires were applied, one of them before the implementation of the activities, so I could make a profile of my students and know their perception about the reading plan activities. A second instrument was applied during the last activities proposed, so I could know the students' perceptions about the Interactive Model. Students' journals were used to know their percep- 
tion of the reading plan before, while and after the implementation. With the journals students had the opportunity to express themselves about the activities of the reading plan, their difficulties and the advances they could have along the process. Finally, the activities as workshops (artifacts) developed by my students contributed to identify their reading process in a foreign language. I collected their jobs after each reading plan lesson.

The procedures to collect all the data started since the application of the first questionnaire. When applying this instrument I noticed my students did not know what to answer, they thought the answers had to be right. So I had to explain again the purpose of the instrument and that they could be free to answer what they wanted.

In addition, I explained in depth the purpose of the project and I highlighted the importance of their role along the development of the activities proposed. The first aspect in which my students felt involved in all the process was when they had the possibility to choose the books they were about to read. I showed them the possible books to work with during the term according to their English level and age and they selected the stories that called their attention due to the images in the cover page or the similarity to other stories they were interested in. Then, I designed the pedagogical platform composed of sixteen sessions, one hour per week, which allowed them to take advantage of the reading plan to improve their reading comprehension process. This platform also included eight different worksheets to be developed by the students in order to help them use the reading strategies based on the interactive model. The workshops were done in different sessions and made part of the three different stages I observed: pre-reading, while-reading and post-reading. After each activity, the students wrote their journals including the description of the activity developed and their perceptions about the activity and their own processes. In the same way, I wrote the field notes with the most relevant aspects I observed after the session and added my comments about my students' progress.

\section{Data Analysis}

In order to analyze the data I adopted the a priori approach in which the researcher looks for things that were determined in advance (Freeman, 1998). In other words, I applied preexisting categories to the data I gathered taking into account the Interactive Model that was chosen to propose the activities for the reading plan.

In this research the process for data analysis followed the four elemental activities mentioned by Freeman (1998), namely: grouping, finding relationships, data displaying and naming. These activities were developed to apply the themes and concepts determined previously to the data gathered and to guide their interpretation in agreement with the a priori approach explained before. The categories and subcategories established were organized in a diagram; each one of them is related to one of the research questions leading this study (see figure 2).

FIGURE 2

Visual representation of the categories resulting from the analysis

CATEGORIES OF THE STUDY

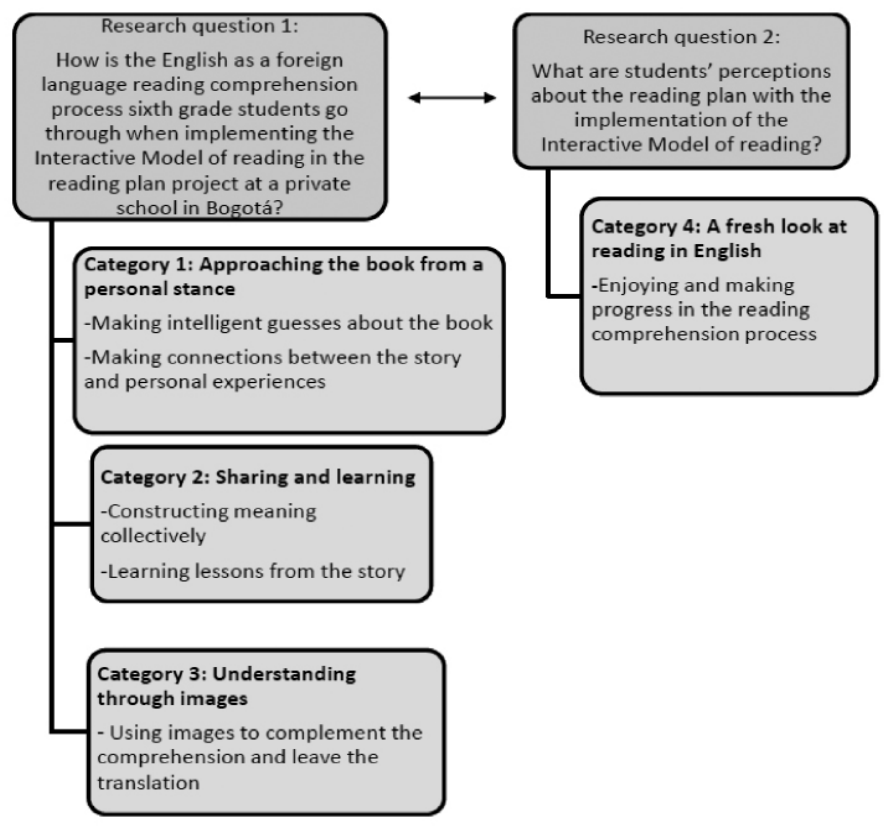




\section{Category 1: Approaching the book from a personal stance}

This category is related to the data gathered from the pre-reading activities when implementing strategies derived from the interactive model of reading. In these activities students showed how they approached the book and started the reading comprehension process. The category refers to the way students made predictions about the books based on the images and titles as one of the first contributions of the model implemented, as well as the connections they started to create with their own lives, their background knowledge and the stories they were about to read thanks to the possibility of activating their schemata and use it to help them comprehend.

The first encounter students had with the book was looking at the images and titles presented in the stories and in each chapter. With this strategy readers are able to activate their background knowledge about the story. In this research students used images and titles to predict different events and thus have a general idea about the book. After that, students could connect the elements they predicted with their experiences and prior knowledge so they could recognize that the stories had settings and characters that they probably knew because they had read something similar, they had watched movies about the stories or they had visited similar places. In this way, students were prepared to approach the book with more elements that allowed them to comprehend what they were reading and relate the new information to their personal and meaningful experiences.

The following example illustrates how the students made connections with the book based on experiences from the past, so they approached the story with previous ideas and background knowledge.

One of the students asked me to clarify one of the questions in the worksheet. The question was "Is the place/time familiar or unfamiliar to you?" When I explained to him the meaning of the question he said: "es como si compararas el lugar de la historia con alguno que yo ya conozca, ¿cierto teacher? Then he said that he was going to write that the setting was familiar because he already knew different beaches and one island when he went to San Andrés and that place was similar to the one observed in the pictures of the Swiss Family Robinson story. I was pleased because of his answer and noticed that some of the students seemed to connect their experiences with the places from the book and started to make interesting guesses about the stories.

(Field note 2. April 12th, 2012)

\section{Making intelligent guesses about the book}

Before reading the book students had the possibility to share their guesses about their stories. The idea of this activity was to help them use their previous knowledge and background so they could succeed in comprehending what they read. According to Carrell (1998), background knowledge of text has a major impact on whether or not a reader can comprehend a text. In the following excerpts it is shown that students were able to guess aspects related to the stories based on what they saw for the first time in the cover page of the books: the illustration and the title.

I think my book is about the family that is lost because a storm in the sea. The family live in the island.

(Artifact 1/The Swiss Family Robinson. S4. March 29th, 2012)

The story is on a golden statue that he realized the poor of their city and one day come a swallow tired and lay down on the base of the statue.

(Artifact 1/The young king and other stories: The Happy Prince. S2. March 29th, 2012)

I think my book is about a man traveling on a boat and one day the boat crashes and the man gets to an island, and he is very big and the people of the island are very small.

(Artifact 1/Gulliver in Lilliput. S18. March 29th, 2012)

I think my book is about fairy tales and this storys are very interesting because the storys are of the Grimm brothers [sic].

(Artifact 1/Five famous fairy tales, S11. March 29th, 2012) 
Data show that students made intelligent guesses because all the aspects mentioned were related to the stories; they did not say anything out of context or improbable; instead, they expressed their thoughts and guesses including the things they already knew and saw. According to Carrell (1998), prior knowledge or schemata is organized and stored in the reader's mind, this schema can be activated through images. With the model, students could activate their schemata to comprehend the new information using the clues given by the writer, in this case, the images and titles.

With the guesses they made, students could reconstruct the possible content of the stories and were prepared to create meaning when they confirmed if their predictions were true or not. This author also mentions that by introducing graphics that illustrate a couple of examples that will be presented in texts and previewing the chapter in a book by examining headings and illustrations, teachers are able to prepare students for texts they may not be familiar with (Carrell, 1998).

\section{Making connections between the story and personal experiences}

As it was mentioned before, readers comprehend better if they use their background knowledge before reading the stories. Carrell (1998) argues that schemata are also the individual's previously acquired knowledge. Students showed they could complement the ideas presented in the story relating some aspects with their experiences. With the schemata they had, they were able to produce hypotheses about the information in the text.

For the students, it was useful to relate some aspects of the stories they were about to read with previous experiences. They could remember familiar places or characters and with those elements they could create a general idea and a mental image of the story, which facilitates its comprehension. With the following examples the previous idea is illustrated:

S3: "En una guia poner poner [sic] los personajes, describirlos, poner los lugares y el tiempo y relacionarlo con lo que yo he leído o he visto sobre la historia.
Me gusto pues ya se mas o menos de lo que se trata la historia. Describir los personajes fue fácil y me gusto acordarme si yo he leído o he visto algo sobre la historia. Me gusto la actividad".

(Journal 2. April 12th, 2012)

S4: "La actividad fue hacer una relación con nosotros y describir parte del libro, además teníamos [que] ver las imágenes y hacer un taller y socializarlo con un compañero que tenga el mismo libro. Parecio muy bueno y además me permite conocer cada vez mejor el libro me gusto"

(Journal 2. April 12th, 2012)

As this piece of evidence shows, students recognized the usefulness of relating the story with personal events of their lives; they could remember important aspects that helped them comprehend the story better. Moreover, they could share those experiences with a partner so they helped each other identifying the characters, the setting and the time. It seemed they could know more about the book thanks to this strategy.

S13: "Hoy la actividad fue informar si el lugar donde se desarrolla es familiar con uno y por ultimo si nosotros emos [sic] visto esos lugares.

Me gusto pues uno aprende todo lo que se necesita del libro y aprendemos cada día mas"

(Journal 2. S13. April 12th, 2012)

During this activity I noticed that some of the students started to talk about their last vacations in San Andres, they mentioned that this island is similar to the image seen in the book The Swiss family Robinson. With this kind of relation students may create a clear image of the setting of the story.

(Field note 2. April 12th, 2012)

Making connections between the story and personal experiences allowed students to create a bond with the text; they felt motivated through reading and activated the knowledge they needed to understand better the books in the foreign language. 
It is noticeable the importance of helping students use their previous knowledge to approach the book giving them the necessary elements to keep in mind what they already know and use it during the reading. With the model, teachers are able to guide the process of reading asking questions that allow students to activate their schemata and be prepared for the reading. With the pre-reading strategies developed based on the model, such as sharing their experiences or asking about familiar elements, students could activate the appropriate background knowledge, which helped them comprehend the text.

\section{Category 2: Sharing and Learning}

This category makes part of the while-reading activities and it is composed of two significant subcategories. The first one explains how students started to construct meaning when they had the opportunity to work in pairs or groups. Some of the activities were planned to be developed in groups or in pairs. When students had the opportunity to interact among them, they complemented their ideas and helped each other comprehend what they were reading. The second subcategory shows that through the reading students learned from the stories, they demonstrated their comprehension of the reading when they were able to express ideas about important lessons for their life and not only giving literal answers that could be found in the text.

As can be seen in the following excerpts, students mentioned that they could comprehend better and remember key vocabulary when they worked in groups. They found their partners' help useful during the reading process because they could complement each other with their ideas. Data show that students discussed their reading to clarify unknown vocabulary and understand the main idea of the texts. According to Wallace (1992), interactive approaches help students make connections with each other and have the potential to lead them to the discovery of knowledge (p. 327).

In some of the groups I noticed that one of the students read and at the end asked his partners what they understood. Then they complemented their ideas together trying to read complete sentences. When someone in the group did not know a word the rest helped him to understand, most of the times saying the word in Spanish. In all the groups the participation is active; they contributed in the construction of meaning.

It is remarkable that when they work in groups they seem to understand the text, they were making meaning together.

(Field notes 3. April 26th, 2012)

When students had the opportunity to interact among them in order to discuss the meaning of the story, they had to negotiate and share the same thoughts. They could comprehend complete sections of the chapters because they complemented each other. According to Grennon \& Grennon (1999), "having an opportunity to present one's own ideas, as well as being permitted to hear and reflect on the ideas of others, is an empowering experience. The benefit of discourse with others, particularly with peers, facilitates the meaning-making process" (p. 110).

S20: "la actividad me pareció divertida porque entiendo más el vocabulario en grupo, porque mis compañeros explican muy bien".

(Journal 13. April 26th, 2012)

S9: "Nos acordamos de palabras que habíamos olvidado y supimos su respectivo significado de cada palabra porque pudimos trabajar en equipo ayudándonos unos a otros".

(Journal 3. April 26th, 2012)

The data revealed that students recognized the usefulness of working in groups in order to understand some words that gave sense to the text without using dictionaries or translators. Helping each other they constructed the general idea of the text and gave meaning to the written words. Students with lower level of English felt more confident and supported while reading the book thanks to their partners' help. Besides, in the group students were able to confirm their guesses and obtained more information to complement their comprehension. 
In addition, in this category it was also noticeable that some students who did not understand some words used the context and their previous knowledge to decide what the word was as the interactive-compensatory model proposes. On the other hand, the students who were skilled at word recognition but did not have enough knowledge about the topic relied on the bottom-up processes to give meaning to the text and in this sense share their ideas with their partners and complement their thoughts to achieve comprehension.

\section{Learning lessons from stories}

One of the ways students showed comprehension of the stories was that they could talk about what they learned from the texts. They did not mention facts based on the stories; instead, they expressed themselves about important lessons for their daily life learned from the readings.

All the data provide a clear evidence of the lessons learned by the students after reading part of the stories. During this session, students focused on the principal aspects that they could abstract from the story and helped them recognize they already understood the text.

S3: "I learn that the rich people can help to the poor people. Everybody can help".

(Artifact 5. May 11th, 2012)

S4: "Yo aprendí que siempre si trabajo en equipo esforsandome, dedicandome y trabajando en equipo me $\mathrm{v}$ air bien [sic]. Esto me lo enseño The Swiss family Robinson".

(Artifact 5. May 11th, 2012)

S6: "In story the table, the donkey and the stick I learned the good people always have compensation and the villan recive [sic] punishment".

(Artifact 5. May 11th, 2012)

S13: "Yo aprendí en la historia The young king que las apariencias engañan ya que el niño era una persona que vestía ropa muy dañada, fea, sucia, que olía mal y la gente lo miraba como un pobre pero nadie se esperaba que iba a ser un muy buen rey".

(Artifact 5. May 11th, 2012)
From the previous examples, it is clear that students not only decoded the texts as it was done years ago in the reading plan activities, or were attached to a dictionary to show their understanding of every single word. In contrast, they were active agents in the construction of meaning, being reflective upon the stories they read. Students could connect with the stories and had a purpose to read.

It is relevant to mention that students were able to comprehend what was implicit in the texts and the author wanted to transmit. Students showed they were beyond the surface of the text and aimed one of the principal purposes of reading, interacting with the text, the author, and their own knowledge to learn meaningful lessons for their lives.

\section{Category 3: Understanding through images}

During the whole process students used the images provided by the text to help them complement the written words. Pictures gave students enriching details that they used to clarify their doubts, so they could continue reading. Additionally, with the images students stated they could avoid the constant translation they were used to. Likewise, students used images to show comprehension, they generated images based on the text showing the main ideas they understood from the text.

\section{Using images to complement the comprehension and leave the translation}

The activities proposed tried to promote that students could use different tools in order to help them comprehend the stories. In this case, the images in the book provided the specific details students needed to complement what they understood only by reading. With the pictures students could create a mental model and activate their schemata so the reading was easier to understand.

S9: "Con la actividad de hoy pude entender un poco más sobre que pasa en mi libro al final basándome en las imágenes del libro".

(Journal 7. May 30th, 2012) 
S13: "Descubrí que me ayudo bastante por imágenes también me ayuda el leer en grupo y explicar lo entendido".

(Journal 7. May 30th, 2012)

S16: "Yo pude comprender el final de la historia gracias a las imágenes”.

(Journal 7. May 30th , 2012)

Evidences show that children used images as a support to complement what they knew. By using the pictures, they could have a guide to clarify the reading, and the unknown vocabulary could be understood through images, also, they could express comprehension of the story read when they used illustrations. For them, it was easier to explain their own drawings and summarize their own ideas.

\section{Category 4: A fresh look at reading in English}

Regarding students' perceptions about the reading plan project when implementing strategies based on the Interactive Model of reading, the data showed students changed their vision about it. Students recognized they progressed in their learning process, enjoyed the activities and the readings and learned strategies that might help them understand other kind of texts in English or in their mother tongue.

Before the implementation, students thought the reading plan was interesting and developed activities such as comics, oral presentations, puzzles to review vocabulary, description of the characters and many written exercises. Even though, they did not comprehend the stories because the exercises developed did not allow them to do so. In addition to that, children said they did not have the opportunity to choose books they liked and most of the times they read stories they were not interested in so they did not have a purpose to read.

Enjoying and making progress in the reading comprehension process

Students expressed they enjoyed a lot the activities since the beginning of the project. The activities were appealing for them, so they could see the reading plan from a different perspective. Taking into account the plan is a mandatory activity at the school, students used to perceive it as another part of the class to be assessed, so they could not take advantage of the reading to improve their skills and learn.

S3: "Me parecio muy divertido todo el proyecto, me gusto las actividades las entendía y podía hacerlas en ingles, me gusto mucho.

Aprendi nuevas palabras al leer, entendía los libros y además me ayudaban las imágenes, podía comprender el libro".

(Journal 15. August 10th. 2012)

S 5: "Esta actividad me gusto mucho porque me hizo demostrar que si comprendi el libro y que puedo seguir leyendo libros en inglés".

(Journal 15. August 10th. 2012)

S 13: "Me encantaron las actividades de mi libro, me gusto que en estas actividades logre avanzar mas. Gracias profe porque con estas actividades logre avanzar en mi ritmo con respecto a hablar, escuchar, leer, entender el ingles".

(Journal 15. August 10th. 2012)

The previous data confirmed that students felt the activities from the reading plan after the implementation of the interactive model were funny and they liked them a lot. They expressed they could comprehend the stories they read thanks to all the activities developed along the semester and noticed the progress in their learning process. Besides, they realized they could use the foreign language to express themselves, read and learn.

With the implementation of strategies based on the interactive model children felt they improved their understanding of English books, they comprehended better than before and built meaning. Also, they recognized the use of the strategies proposed as a helpful tool to help them during the reading comprehension process (Figure 1). 


\section{Figure 1}

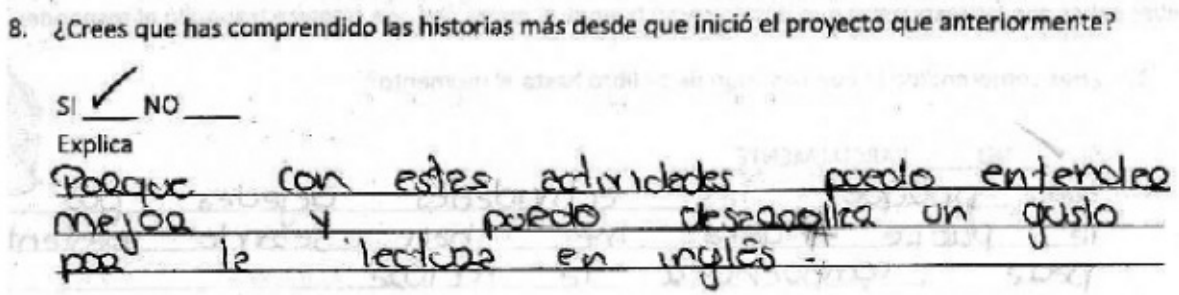

(Questionnaire 2/ June 7th, 2012)

8.

¿Crees que has comprendido las historias más desde que inició el provecto que anteriormente?

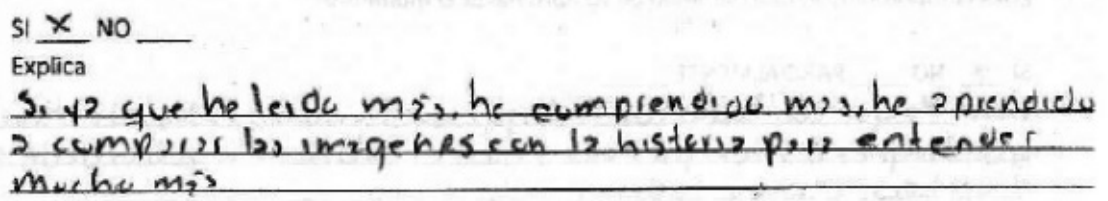

(Questionnaire 2/ June 7th, 2012)

The excerpts above show that along the implementation children were aware of their own achievements and how after each session they enjoyed the stories more and found useful elements that helped them interact with the text, the writer of the story and even their partners to achieve the main goal when reading: comprehension.

It is noticeable that children perceived the reading plan as another resource which helped them to improve some language skills and gave them the opportunity to see this project in a different way, leaving behind translations and dictionaries. Moreover, the motivation toward the reading plan increased and students asked for more activities based on readings chosen by them because they felt confident to express opinions and ideas in the foreign language about topics they found interesting and appealing.

\section{Conclusions and Implications}

This qualitative action research described and analyzed the English reading process sixth grade students went through when implementing reading strategies based on the interactive model of reading in the reading plan project at a private school in Bogotá. With reference to question one, findings suggest that students went through a process which let them create meaning by making intelligent guesses about the reading which helped them activate their schemata and use their background knowledge and experiences in order to make significant connections with the story. The predictions made helped kids to have a general idea about the book, and the connections with personal experiences gave them a clearer idea about the setting, the characters and the time of the story. This means, building schemata played an important role in comprehension. Thanks to it, students did not have to rely on dictionaries because they were familiar with the topic presented and vocabulary. In addition, findings showed that because they could build schemata based on their previous experiences, they were able to predict the sequence of events and better comprehend the text.

The background knowledge students used during the pre-reading activities was complemented along the process when working in groups. The ideas shared among students filled the missing 
parts in each story and allowed them to confirm the guesses made at the beginning. Moreover, students felt confident and supported by their peers when interacting in the activities in order to achieve the purpose of building knowledge.

In the same way, findings revealed how some students who had difficulties at word recognition or decoding, compensated this deficiency using sentence context and previous knowledge to decide the meaning of the words, as seen in the interactive-compensatory model. Conversely, skillful students at word recognition but with not enough knowledge about the text topic relied on bottom-up processes to achieve comprehension. After using these strategies, students shared with their partners their thoughts and complemented the meaning of the story.

What is more, during the process students showed the comprehension of the text by making reflective interpretations of the information given by the author. They could share important lessons learned from the stories demonstrating they interacted with the text, the author and their partners in the process of making meaning.

Additionally, the use of images gave students specific details they could remember in order to clarify doubts and complement knowledge. The words, sentences and paragraphs were understood easily when more images were presented.

One study developed by Echeverri and McNulty (2010) in Colombia was useful to support the findings of this study. The action research project examined the foreign language reading comprehension of eight graders in a public school. They experienced a directed reading-thinking approach with strategies for comprehension and application. During the pedagogical intervention the strategies used were prediction, prior knowledge, graphic organizers, and questions. Findings showed that participants thought that the strategies and an interactive reading task improved reading comprehension. Many students commented that making predictions allowed them to figure out what the topic of the reading was and to express what they thought about it.
In relation to the second question, students found the reading plan project interesting and appealing. They could change the perception they had about it and gave a fresh look at the project. Thanks to the activities the students felt confident and committed to their learning process. They had the chance to be listened to and chose the books for the reading plan. They appreciated more the English texts because they enjoyed them and found a purpose to read. As a result, they did not have to translate the words all the time to try to understand. Children could observe significant progress in their own process and took the risk of expressing themselves in the foreign language or in Spanish about the knowledge they built with the readings.

Additionally, the research study brought out relevant implications for the participants. The most important one is being aware of their role as active agents in the reading process. The reader makes the decision to give meaning to the words and sentences he/she reads using different strategies, in order to comprehend and understand what the writer wants to transmit.

Moreover, with the project students had the opportunity to decide which books they wanted to read and with each activity they could express their ideas and feelings about the stories sharing their experiences and background knowledge to give meaning to the new information they read. In reference to Carrell (1998), the role of the reader in the reading process as an active agent is relevant because the text does not carry meaning itself but rather provides hints that allow readers and listeners to create meaning from prior knowledge. When students have the possibility to relate the stories to their lives, they may feel participants into the process of building knowledge.

Finally, this research provided an excellent insight of how a cognitive model could be transferred to a classroom developing activities in English as a foreign language. Therefore, it became an example of how to transform scientific abstract knowledge into applied instructional and pedagogical knowledge. 


\section{References}

Birch, B. (2007). English L2 reading: getting to the bottom. New Jersey: Lawrence Erlbaum.

Burns, A. (2003). Collaborative action research for English language teachers. Cambridge: Cambridge University Press.

Carrell, P. (1998). Interactive text processing: implications for ESL/second language reading classrooms. In P. Carrell, J. Devine \& D. Eskey, (eds.), Interactive approaches to second language reading (pp. 73-92). Cambridge: Cambridge University Press.

Carrell, P., Devine, J. \& Eskey, D. (Eds.). (1998). Interactive approaches to second language reading. Cambridge: Cambridge University Press.

Carrell, P. \& Eisterhold, J. (1998). Schema theory and ESL reading pedagogy. In P. Carrell, J. Devine \& D. Eskey (Eds.), Interactive approaches to second language reading (pp. 73-92).Cambridge: Cambridge University Press.

Dechant, E. (1991). Understanding and teaching reading: An interactive model. New Jersey: Lawrence Erlbaum.

Echeverri, L. \& McNulty, M. (2010). Reading strategies to develop higher thinking skills for reading comprehension. Profile 12(1),107-123.

Eskey, D. (1998). Holding in the bottom: An interactive approach to the language problems of second language readers. In P. Carrell, J. Devine, \& D. Eskey, (Eds.), Interactive approaches to second language reading (pp. 93-100).Cambridge: Cambridge University Press.

Ferrance, E. (2000). Action research. Providence, RI: LAB Brown University.

Freeman, D. (1998). Doing teacher research. Canada. Heinle \& Heinle.

Gerson, K. \& Horowitz, R. (2002). Observations and interviewing: Options and choices in qualitative research. In T. May (Ed.), Qualitative Research in Action (199-223) London: SAGE publications.

Goodman, K. (1982). Language and literacy. Boston: Routledge \& Kegan Paul.

Goodman, K. (1998). The reading process. In P. Carrell, J. Devine, \& D. Eskey (Eds), Interactive approaches to second language reading (pp. 11-21).Cambridge: Cambridge University Press.
Grabe, W. (1998). Reassessing the term interactive. In P. Carrell, J. Devine \& D. Eskey, (Eds.), Interactive approaches to second language reading (pp. 56- 70). Cambridge: Cambridge University Press.

Grennon, J \& Grennon, M. (1999). In search of understanding: The case for constructivist classrooms. New York: AsCD Publications.

Hedge, T. (2000). Teaching and learning in the language classroom. Oxford: Oxford University Press.

Johnson, B. \& Christensen, L. (2004). Educational research. Quantitative, qualitative and mixed approaches. London: SAGE.

Johnson, P. (1981). Effects on reading comprehension of language complexity and cultural background of a text. TESOL Quarterly.

Merriam, S. B. (1998). Qualitative research and case study applications in Education. San Francisco: Josey-Bass.

Navarro, A. (2008). Building schema for English language learners. Retrieved from ERIC database. (ED514335).

Nuttall, C. (2000). Teaching reading skills in a foreign language. London: Heinemann.

Rayner, K. \& Pollatsek, A. (1989). The psychology of reading. New Jersey: Lawrence Erlbaum.

Rodríguez Hernández J. \& Rodríguez Bulnes, G. (2009). Reading comprehension strategies: A case study in a bilingual high school. Revista Electrónica Matices en Lenguas Extranjeras, 3.

Rumelhart, D. E. (1980). Theoretical models and processes of reading. Newark DE: International Reading Association.

Samuels, J. \& Kamil, M. (1998). Models of the reading process. In P. Carrell, J. Devine, \& D. Eskey, (Eds), Interactive approaches to second language reading (pp. 23- 36). Cambridge: Cambridge University Press.

Stanovich, K. E. (1980). Toward an interactive-compensatory model of individual differences in the development of reading fluency. Reading Research Quarterly.

Urquhart, A. H. \& Weir, C. (1998). Reading in a second language: Process, product and practice. London: Longman.

Wallace, C. (1992). Reading. Oxford: Oxford University Press.

Zúñiga, G. (2001). Constructing literacy from reading in first and second language. Neiva, Universidad Surcolombiana: OTI Impresos. 